\title{
Trade Union Cooperation in the EU: Views Among Swedish Trade Unions and Their Members
}

\section{Bengt Furåker' and Mattias Bengtsson}

Department of Sociology and Work Science, University of Gothenburg, Sweden

\begin{abstract}
This article compares views among Swedish trade unions with those of their members regarding cross-national union cooperation in Europe or the EU. Data are derived from two different surveys, one among trade unions in 2010-2011 and the other among employees in 2006. It turns out that trade unions are generally more affirmative than their members to transnational union cooperation. In the employee survey, differences appear between members of the three peak-level organizations - the LO (manual workers), the TCO (white-collar workers), and Saco (professionals). However, controlling for education, these differences cannot be verified statistically. Higher education - which above all Saco members have - is linked to more positive attitudes toward transnational union cooperation. The gap between the organizations and their affiliates concerning engagement in European issues appears to be larger in the LO than in Saco, with the TCO somewhere in the middle.
\end{abstract}

\section{KEYWORDS}

Swedish trade unions / transnational trade union cooperation / logic of influence / logic of membership / survey data

he development of the EU brings about many challenges for trade unions, the aim of which is to improve or defend members' employment and working conditions. Besides the task of trying to increase or keep up wages, unions are involved in all kinds of other issues and to some extent they even play a political role. There is a wide range of possible actions and measures to take, implying that unions-given that they cannot do everything-must choose what they should spend their energy and resources on. The process of EU integration raises the question as to what extent it is desirable for them to engage in EU-level issues compared with issues closer to home-at national, regional, local, or workplace level. It may be that union officials develop priorities that are separate from what ordinary members would like to see. Our main research question is therefore whether the views of trade unions coincide with or deviate from those of their membership. Yet another issue to be dealt with is whether, in this connection, unions differ from one another due to which socioeconomic categories they organize.

In the present article, we throw new light on these topics by comparing certain views of Swedish trade unions with those of their members regarding transnational union cooperation in Europe or the EU. Data from two surveys-one with employees in 2006 and the other with trade unions in 2010-2011-are being used. Sweden is undoubtedly an interesting case, as it has been described as one of the most Euroskeptic

\footnotetext{
${ }^{1}$ E-mail: bengt.furaker@socav.gu.se
} 
countries (e.g., Archer 2000; Dølvik 1997; Hyman 2009). At the same time, Swedish trade unions are rather much engaged in the activities of the European Trade Union Confederation (ETUC).

\section{Swedish trade unions and the EU-a background}

Union density has declined in Sweden since the mid-1990s, but a recent comparison of 18 economically advanced countries shows the Swedish rate to be the highest with $71 \%$ in 2009 (Kjellberg 2011, pp. 47-48). The Finnish and Danish percentages are close (70\% and 68\%, respectively, in 2008), whereas the figures for all other countries range from just above $50 \%$ (Belgium and Norway) down to $8 \%$ (France). The three main Swedish confederations-the LO (manual workers), the TCO (white-collar workers), and Saco (professionals) - are to an unusually high degree class based; in turn, they broadly represent blue-collar workers, white-collar workers, and professionals. In 2009, their proportions of total union membership were about $47 \%, 34 \%$ and $17 \%$, respectively, which leaves $3 \%$ for other organizations (Kjellberg 2011, pp. 53-54).

In dealing with attitudes toward transnational union cooperation in Europe, we must be aware that trade unions are strongly rooted in the institutional structures of the nation state (Magnusson and Murhem 2009, p. 185; Martin and Ross 2001, pp. 53-54). Being embedded in national industrial relations and welfare state institutions, they show more or less skepticism toward European integration and the creation of a European social model (cf. Busemeyer et al. 2008). Their skepticism varies, among other things, due to the great cross-national differences in social and economic standards. Swedish union members tend to think that they have little to gain from cooperating with less successful organizations. When they were asked about which tasks the union should work with, "union cooperation in Europe" was ranked number 15 of 18 and significantly higher proportions instead preferred traditional union objectives as "job security," "income security," "work environment," and "wages and wage negotiations" (LO 2012, pp. 42-44).

The public opinion in Sweden has largely been rather negative to the EU. This also goes for Norway and Denmark, although only Norway has refused EU membership. "Scandinavian exceptionalism," "reluctant Europeans," and "the outposts of Euroscepticism" are typical descriptions of the three countries and their citizens (Archer 2000, p. 87; Gstöhl 2002; Hyman 2009, p. 8; Miljan 1977). Sweden voted for EU membership in 1994, but in 2003 a clear majority turned down entry into the European Monetary Union (EMU). In the 1994 referendum, LO, TCO, and Saco leaders generally supported EU membership, but officially the LO took a neutral position as the affiliated organizations were divided and many grassroots members were strongly negative (Archer 2000; Hyman 2009, p. 11). Concerning the EMU referendum in 2003, the LO again took a neutral position, but there was in fact a split within the organization with the Metal-Workers' Union and the Industrial Union being strongly positive and the Commercial Employees' Union and the Transport Workers' Union being strongly negative (Aylott 2005, pp. 552, 556; Hyman 2009, pp. 14-15; Widfeldt 2004, p. 509). Actually 69\% of LO members, $53 \%$ of TCO members, and $45 \%$ of Saco members voted no, when the introduction of the Euro was rejected with almost 56\% versus 42\% (Widfeldt 2004, p. 513).

Since the middle of the 1990s, however, Swedish union members have by and large become more positive to Swedish membership in the EU, but at the same time the 
differences between the three confederations have increased. While as many as $69 \%$ of Saco members were positive to EU membership in 2010, the corresponding proportion among LO members amounted to no more than 26\% (Holmberg 2012, p. 8). TCO affiliates took an in-between position with $49 \%$ having a positive view.

A study of Nordic metal trade unions' views of engagement in European-level policymaking has underscored the split in opinions (Andersen 2006, p. 34). It shows that union officials recognized a growing need to make their voice heard more strongly, a view markedly in contrast to the otherwise skeptical attitude among unions in Denmark, Norway, and Sweden. One strategy to obtain increased European-level influence is to strengthen the Nordic cooperation at sectoral level, which has occurred especially among the Nordic metal trade unions (Magnusson and Murhem 2009, p. 194). Yet another study of the Swedish unions in the metal industry and their international strategies stresses their increasing focus on European trade union cooperation (Blomqvist and Murhem 2003, p. 194). Still, they have taken a more reactive than active stance and they have been reluctant to hand over decision-making power to the European Metal-Workers' Federation (now industriAll).

The Swedish participation in the European integration process has been described as "elite-driven, with the public following slowly and without enthusiasm" (Widfeldt 2004, p. 504). Now this is not unique for Sweden; there is generally more support of the EU among elite groups than among ordinary people (cf. Aylott 2005, p. 546; Hooghe and Marks 2006; Hyman 2005; Kohli 2000, p. 125). In a survey of all the EU referendums 1986-2009 (on accession, treaties, EMU entry, and bilateral agreements), it turns out that manual workers have to a disproportionate degree voted "no" (Hyman 2009, p. 28). Thus, class position seems to have an impact on political attitudes. However, there is research emphasizing the explanatory power of education for ideological orientations along "a new politics dimension"-besides the "traditional" left/right ideological dimension-in advanced industrial democracies. The transmission of libertarian values in the educational milieu appears to make people less authoritarian and less nationalistic (e.g., Bengtsson et al. forthcoming; Stubager 2008). According to this perspective, it is education rather than class in itself that is the main explanatory mechanism behind the divergent attitudes to European integration. On the other hand, education may be seen as an aspect of class divisions.

A comparative international survey from 2010-2011 designed to capture the views of officials in unions affiliated to one of the European Trade Union Federations reveals that Nordic trade unionists were more skeptical about the EU project than those from other regions: "Northern reluctance, scepticism and, sometimes, indifference towards a European approach was the most unambiguous and striking finding" (Glassner and Vandaele 2012, p. 21). Although it can be discussed what Euroskepticism stands for (Hyman 2009, p. 6), there are certainly highly skeptical attitudes to the EU among Swedish unions and their members. The question is whether this affects the willingness to participate in transnational union cooperation in the EU. One important aspect is the role of the ETUC. It might be expected that the general Euroskepticism has some bearing on attitudes to union cooperation through the ETUC as such cooperation implies involvement with many EU institutions. There is obviously a limited "capacity of the Community to build an EU-level industrial relations arrangement," because of the economic bias of the European integration project and the weakness of the European social partners in relation to their national affiliates (Dølvik and Visser 2009, p. 505).

European trade unions are generally overwhelmingly positive to joint transnational efforts, but it is still a long way to go to make their cooperation a large-scale reality 
(Furåker and Bengtsson 2013). One example of the difficulties in developing transnational union cooperation is the issue of statutory minimum wages (e.g., Eldring and Alsos 2012; Furåker and Lovén Seldén forthcoming 2013; Schulten 2008; Schulten and Watt 2007; Vaughan-Whitehead 2010). Most of the EU member states have legislated minimum wages, but the Nordic countries do not. There is a great deal of resistance among Nordic trade unions to such legislation, whereas many other European unions are strongly positive. Union strength in terms of membership and bargaining power is apparently a major factor behind the diverging attitudes. Those in favor of statutory minimum wages mainly argue that this solution helps to protect vulnerable workers and to prevent wage dumping. The principal argument among the opponents is that legislation threatens a successful bargaining model, in which wages are decided by independent social partners without interference by the state. It is also suggested that unions would get greater difficulties in recruiting members if wages be determined by law.

These differences in trade unions' attitudes to legislation on minimum wages have been discussed intensely within the ETUC in recent years. It will certainly be difficult to carve out a truly joint position among European trade unions, as national models are still in command. To avoid that the different views among the member organizations lead to open conflict, the ETUC has tried to strike a balance between the diverging interests. Its most recent strategy and action plan include a declaration that it "will support its members' initiatives... in the pursuit of fair wages for all European workers including supporting union campaigns for effective minimum wages in those countries where unions consider them necessary" (ETUC 2011, p. 54). In other words, the national trade unions are supposed to decide themselves how they want to go ahead.

The legitimacy and support for the European integration process also risks to be undermined by the judgments by the European Court of Justice in the "Laval Quartet" (the Laval, Viking, Rüffert, and Luxembourg cases). These judgments have been described as an encroachment into member states' sovereignty over social policy, labor law, and industrial relations (Dølvik and Visser 2009, pp. 492, 504). The principles of free movement seem to be more fundamental than the rights of industrial action. If unions perceive that the nationbased constitutional rights to form industrial relations are seriously threatened, they may withdraw their support for the European integration project.

\section{Two competing logics}

As seen above, union leaders' and union members' attitudes toward the EU diverge. The former tend to be relatively more positive and the latter to be relatively more negative. It has been claimed that the organizations are confronted by "serious strategic dilemmas," as there has developed "a dangerous gap" between their more positive official policies and members' more hostile attitudes toward Europeanism (Hyman 2005, p. 10). If unions become too engaged with EU institutions they may risk to "succumb to an elitist embrace" (Hyman 2005, p. 24). Union participants in the Brussels machine, "trade unionists in suit and tie," run the risk of distancing themselves from their members as they embrace an elite discourse: "Eurospeak" (Hyman 2005, pp. 26, 28). In addition, ETUC-led action has to a large extent been a top-down process rather than Europeanization from below, and it has "largely developed by borrowing resources from European institutions" (Martin and Ross 2001, p. 74). 
To use two concepts that have been applied on trade unions as well as on business associations (e.g., Dølvik 1997; Dølvik and Visser 2001, pp. 24-25; Schmitter and Streeck 1999, pp. 19ff), it may be argued that union officials suppress a "logic of membership" and promote a "logic of influence." The logic-of-membership concept refers to the policies of organizations that "maintain their representative credentials by articulating the wishes and interests of their constituents" (Hyman 2005, p. 24). Members must be offered sufficient incentives so that the organizations can "extract from them adequate resources to ensure their survival” (Schmitter and Streeck 1999, p. 19). The logic-of-influence concept implies that organizations "adapt their aims and methods to the actual decision-making processes on which they wish to exert an impact" (Hyman 2005, p. 24). They must be organized in such a way that they can "gain access to and exercise adequate influence over public authorities (or conflicting class associations)," thereby extracting sufficient resources "enabling them to survive and to prosper" (Schmitter and Streeck 1999, p. 19). The two categories should not be treated as mutually exclusive, but ideal-typically trade unions with a logic-of-influence approach focus on what can be accomplished through interaction with other actors, whereas those with a logic-of-membership perspective are above all inclined to meet their members' wishes.

\section{Data and variables}

We use Swedish data from two surveys to throw light on the questions in focus. A first survey was conducted in 2006 with a random sample of employees in Sweden. The regular Labor Force Survey (LFS) was used as sampling frame and we also have access to LFS data for all the respondents in the dataset. At the end of the LFS telephone interview, participants were asked whether they would be willing to answer a questionnaire on working conditions, job change, etc. Those who accepted received the survey by mail. A total of 1851 questionnaires were filled in and returned. Calculated on those who agreed to participate, the response rate is $72 \%$, but if we also include those who declined, it merely reaches $52 \%$. Among other things, respondents were asked about their attitudes to various issues related to trade union policies in the EU. The dataset includes information about whether people were members of the LO, TCO, Saco, or other unions or were non-unionized.

The second survey was carried out in 2010-2011 with a large number of trade unions in European countries. We have access to information from 250 organizations, but the present article just focuses on the data from Sweden where 39 unions were selected for participation. These 39 include the three peak-level organizations-LO, TCO, and Saco-and their main member organizations. Except for two unions, all responding units had at least 10,000 members and as many as 20 unions had 50,000 members or more. The return of questionnaires was indeed a success; the response rate was $100 \%$.

There is hence a time lag of about four years between the two surveys, which might of course to some extent impact on the outcome. As mentioned, since the mid-1990s public opinion in Sweden has become more positive to the EU (Holmberg 2012). Looking more closely at what has happened between 2006 and 2010, we find that the proportion in favor of Swedish membership in the EU increased from 43 to 53\%. However, it appears rather unlikely that employees would have become considerably more positive to cross-national union cooperation, as the financial and economic crisis in the EU has probably had a restraining effect. 
The questions and the response options are not formulated in exactly the same way in the two surveys, but some of the items may nevertheless allow meaningful comparisons of the opinions of unions and their members. To begin with, we have two rather similar statements on the long-term effects of trade union cooperation in the EU or Europe. In the union survey, respondents were asked to what extent their organization agreed with the statement "Cross-national union cooperation will, in the long run, improve the conditions for European workers." The employee survey had a very similar statement: "Union cooperation will, in the long run, improve the conditions for wage-earners in the EU." There were some differences with respect to the precoded response options. In the union questionnaire, respondents were invited to choose one of the following alternatives regarding to what extent their organization agreed: "Yes, to a high degree," "Yes, to some degree," "Only to a low degree," or "No, not at all." In the employee survey, respondents were asked whether the statement corresponded "Very well," "Rather well," "Neither well nor poorly," "Rather poorly," or "Very poorly" with their own opinion.

We also have two rather similar measures on whether trade unions should engage less in issues at the European or the EU level. The questionnaire to trade union representatives included the statement "Unions should engage less in issues at the European level." In the employee survey, the parallel statement was a bit longer, but its meaning was nearly the same (although this might be discussed; see further below): "Swedish unions should engage less in issues at the EU level and more in improving working conditions in Sweden." The response options linked to the two items were the same- and thus entail the same differences-as mentioned above.

The employee survey allows more elaborate statistical analyses and we have run some logistic regressions, in which the impact of a number of factors is scrutinized. A major purpose is to examine whether there are differences in response patterns related to union affiliation, but we also want to see what it means to be a union representative and to take part in some kind of union activity. Having an assignment in an organization normally implies that one is likely to speak on behalf of it. Union representatives of course have different positions in the organizational hierarchies, but we do not have access to that kind of information. To continue, being a union representative involves participation in the organization's activities, but members without any assignment can also participate in such activities, perhaps then more occasionally. As control factors in the regressions we include sex, age, education, sector of employment, industry, size of workplace, type of employment contract, and working time.

Moreover, we make use of some other indicators in the union survey. Unfortunately, we do not have corresponding or similar data for employees, but the ones available in the union survey stand on their own. Respondents were asked to tell to what extent their organizations agreed with two statements that might be seen as expressions of a logicof-influence view: "To increase their power and influence, the ETUC member organizations must be prepared to transfer authority to the ETUC" and "It is necessary for the ETUC to adapt its aims and methods to the actual decision-making processes in the EU." The latter statement is close to the definition of logic of influence suggested by Richard Hyman (2005, p. 6) and quoted above.

A third statement has more of a logic-of-membership focus, but we should then keep in mind that the ETUC does not have individuals but organizations as members. It reads "The ETUC should increase its efforts to mobilize and pursue the interests of its member organizations." Agreeing with it means that one wants to see increased efforts 
to mobilize affiliate organizations - and presumably also their members-and to pursue their interests. This item is apparently a matter of whether trade unions find it important that the ETUC does not embark on a road separate from the interests of its members. On the other hand, it also represents a top-down perspective, as it is assumed that the initiative to mobilization would come from the ETUC.

\section{Results}

\section{Unions' engagement in Europe or the EU}

We start the presentation of results by looking at how respondents in the two surveys perceive the effects of trade union cooperation in Europe or the EU (Tables 1 and 2). About $80 \%$ of the LO and TCO organizations consented to a high degree that European workers would benefit in the long run from more transnational union cooperation. The remaining unions belonging to these two peak-level organizations answered "Yes, to some degree." In contrast only $40 \%$ of the Saco unions chose the most positive alternative, but adding the second most positive answers they reach $87 \%$. One of the Saco organizations ticked "Only to a low degree" and another could not provide an answer.

Table I Degree of agreement among Swedish unions with the statement "Cross-national union cooperation will, in the long run, improve the conditions for European workers." (in percentages)

\begin{tabular}{ccccccc}
\hline & $\begin{array}{c}\text { Yes, to a high } \\
\text { degree }\end{array}$ & $\begin{array}{c}\text { Yes, to some } \\
\text { degree }\end{array}$ & $\begin{array}{c}\text { Only to a low } \\
\text { degree }\end{array}$ & $\begin{array}{c}\text { No, not } \\
\text { at all }\end{array}$ & $\begin{array}{c}\text { Do not } \\
\text { know }\end{array}$ & Total \\
\hline LO & 79 & 21 & 0 & 0 & 0 & $100(14)$ \\
\hline TCO & 80 & 20 & 0 & 0 & 0 & $100(10)$ \\
\hline Saco & 40 & 47 & 7 & 0 & 7 & $100(15)$ \\
\hline Total & 64 & 31 & 3 & 0 & 3 & $100(39)$ \\
\hline
\end{tabular}

Table 2 Correspondence between the statement "Union cooperation will, in the long run, improve the conditions for wage-earners in the EU" and employees' own view. Percentages by union affiliation.

\begin{tabular}{lccccccc}
\hline & $\begin{array}{c}\text { Very } \\
\text { well }\end{array}$ & $\begin{array}{c}\text { Rather } \\
\text { well }\end{array}$ & $\begin{array}{c}\text { Neither well } \\
\text { nor poorly }\end{array}$ & $\begin{array}{c}\text { Rather } \\
\text { poorly }\end{array}$ & $\begin{array}{c}\text { Very } \\
\text { poorly }\end{array}$ & $\begin{array}{c}\text { Do not } \\
\text { know }\end{array}$ & Total \\
\hline LO & 6 & 22 & 22 & 4 & 6 & 40 & $100(652)$ \\
\hline TCO & 6 & 30 & 21 & 5 & 4 & 35 & $100(553)$ \\
\hline Saco & 9 & 40 & 19 & 5 & 3 & 25 & $100(241)$ \\
\hline Other & 8 & 33 & 28 & 6 & 0 & 25 & $100(36)$ \\
\hline Non-unionized & 3 & 15 & 21 & 4 & 9 & 48 & $100(300)$ \\
\hline Total & 6 & 26 & 21 & 5 & 5 & 38 & $100(1824)$ \\
\hline
\end{tabular}


Positive views regarding the effects of transnational union cooperation were much less common among the members in all three organizations (Table 2). Few individuals thought that the statement "Union cooperation will, in the long run, improve the conditions for wage-earners in the EU" corresponded very well with their own opinion. Somewhat more respondents said it corresponded rather well. At the same time, there are even fewer individuals on the negative side, because more than one-third of the total answered that they did not know and about one-fifth chose the in-between alternative "Neither well nor poorly."

Yet another interesting aspect is the differences related to which union people are affiliated with. The smallest proportion of positive answers ("Very well" and "Rather well" answers) appeared among the non-unionized and in the LO and the largest in Saco-with the TCO and the category "Other" (which includes only 36 respondents in the table) in the middle. In other words, it seems that the differences between unions and their affiliates are generally largest in the LO, somewhat smaller in the TCO, and smallest in Saco.

The next twin items concern whether unions should engage less in issues at the European or EU level (Tables 3 and 4). The statement presented to employees is more specified. It explicitly refers to Swedish unions and there is also an additional part saying that they instead of engaging in issues at the EU level should concentrate on improving

Table 3 Degree of agreement among Swedish unions with the statement "Unions should engage less in issues at the European level." (in percentages).

\begin{tabular}{ccccccc}
\hline & $\begin{array}{c}\text { Yes, to a high } \\
\text { degree }\end{array}$ & $\begin{array}{c}\text { Yes, to some } \\
\text { degree }\end{array}$ & $\begin{array}{c}\text { Only to a low } \\
\text { degree }\end{array}$ & No, not at all & $\begin{array}{c}\text { Do not } \\
\text { know }\end{array}$ & Total \\
\hline LO & 0 & 0 & 0 & 100 & 0 & $100(14)$ \\
\hline TCO & 0 & 0 & 10 & 90 & 0 & $100(10)$ \\
\hline Saco & 7 & 0 & 13 & 80 & 0 & $100(15)$ \\
\hline Total & 3 & 0 & 8 & 90 & 0 & $100(39)$ \\
\hline
\end{tabular}

Table 4 Correspondence between the statement "Swedish unions should engage less in issues at EU level and more in improving working conditions in Sweden" and employees' own view. Percentages by union affiliation.

\begin{tabular}{lccccccc}
\hline & $\begin{array}{c}\text { Very } \\
\text { well }\end{array}$ & $\begin{array}{c}\text { Rather } \\
\text { well }\end{array}$ & $\begin{array}{c}\text { Neither well } \\
\text { nor poorly }\end{array}$ & $\begin{array}{c}\text { Rather } \\
\text { poorly }\end{array}$ & $\begin{array}{c}\text { Very } \\
\text { poorly }\end{array}$ & $\begin{array}{c}\text { Do not } \\
\text { know }\end{array}$ & Total \\
\hline LO & 22 & 36 & 20 & 4 & 1 & 17 & $100(651)$ \\
\hline TCO & 16 & 34 & 21 & 9 & 2 & 19 & $100(555)$ \\
\hline Saco & 10 & 32 & 26 & 13 & 2 & 17 & $100(241)$ \\
\hline Other & 11 & 33 & 25 & 8 & 6 & 17 & $100(36)$ \\
\hline Non-unionized & 12 & 30 & 19 & 4 & 3 & 32 & $100(301)$ \\
\hline Total & 17 & 34 & 21 & 7 & 2 & 20 & $100(1826)$ \\
\hline
\end{tabular}


working conditions in Sweden. One might argue that the latter qualification is implicit in the statement addressed to unions. However, if employees perceived the statement in terms of a zero-sum game-that is, being less engaged in issues at the EU level frees up more energy and resources for improving working conditions in Sweden-it may have been easier for them to agree. We must therefore be cautious with our conclusions in this comparison.

Almost all the responding union officials disagreed completely with the assertion that unions should engage less in European issues, although we find a few exceptions. The general pattern is that the organizations do not subscribe to a reduction of their European engagement. In contrast, roughly six out of ten LO members, five out of ten TCO members and four out of ten Saco members found that the statement "Swedish unions should engage less in issues at the EU level and more in improving working conditions in Sweden" corresponded very or rather well with their own view (Table 4). This also suggests that there may be a larger gap between LO affiliates and their organizations than between TCO and SACO affiliates and their respective organizations. Again, the proportions answering "Neither well nor poorly" and "Do not know" were relatively high, but this time the former kind of response was for the most part more common than the latter.

The number of respondents in the employee survey makes it possible to analyze the data presented in Tables 2 and 4 somewhat further. Thus, we have run logistic regressions with a series of independent variables included. The dependent variables have been dichotomized; on the one hand, we have those who have answered that the statements corresponded very well and rather well with their own view and on the other hand all the rest. As mentioned before, we examine differences in response patterns related to union affiliation, assignments for unions, participation in union activity, sex, age, education, sector of employment, industry, size of workplace, type of employment contract, and working time. To make the presentation as simple as possible, we show the outcome only for the union-related variables, but we occasionally add some comments on other results. Two models are presented for each of the statements. The reason for this is to show how education affects the outcome on union affiliation. Accordingly, Model 1 includes all the independent variables except education and in Model 2 education is added.

Table 5 displays the results for the main variables as to the propensity to endorse the two statements. On the first statement, Model 1 reveals significant effects of union affiliation and union assignments. Saco members were more inclined and the nonunionized were less inclined than LO members to agree with the statement. There is, however, no significant difference between TCO and LO affiliates, although the coefficient for the former is higher. Employees who were union representatives at the time of the survey as well as those who had had such assignments previously also more often answered in the affirmative than those who had no such experience. In contrast, participation in union activity does not seem to matter very much. Moreover, sex and age come across as important; males tended to be more willing than females to approve of the statement, whereas younger employees tended to be less willing than older employees.

In Model 2, the differences between unions are no longer statistically significant, as education is introduced as an independent variable. People with middle-level and higher education were more likely to agree that employees in the EU would in the long run 
Table 5 Factors impacting on agreement with two statements. Logistic regressions. With control for sex, age, type of employment contract, size of workplace, working time, employment sector, and industry. Odds ratios.

\begin{tabular}{|c|c|c|c|c|}
\hline & \multicolumn{2}{|c|}{$\begin{array}{l}\text { "Union cooperation will, in } \\
\text { the long run, improve the } \\
\text { conditions for wage-earners } \\
\text { in the EU"' }\end{array}$} & \multicolumn{2}{|c|}{$\begin{array}{l}\text { "Swedish unions should engage } \\
\text { less in issues at EU level and more } \\
\text { in improving working conditions } \\
\text { in Sweden" }\end{array}$} \\
\hline & Model I & Model 2 & Model I & Model 2 \\
\hline \multicolumn{5}{|l|}{ Union affiliation } \\
\hline LO (ref.) & I & I & l & I \\
\hline $\mathrm{TCO}$ & $|.3|$ & 1.03 & 0.69** & 0.77 \\
\hline Saco & $2.01 * * * * *$ & 1.37 & 0.55 **** & 0.74 \\
\hline Other & 1.26 & 1.08 & 0.59 & 0.62 \\
\hline Non-unionized & $0.65 *$ & $0.53^{*} *$ & 0.50米米 & 0.55 ***** \\
\hline \multicolumn{5}{|c|}{ Union representative } \\
\hline Yes, at present & $2.05 * * * *$ & $2.08 * * * *$ & 0.85 & 0.84 \\
\hline Yes, previously & $1.92 *$ & 1.72**** & I.I I & 1.12 \\
\hline No (ref.) & 1 & I & I & I \\
\hline \multicolumn{5}{|c|}{ Participation in union activity } \\
\hline Yes & 1.18 & 1.17 & 0.89 & 0.91 \\
\hline No (ref.) & I & I & I & I \\
\hline \multicolumn{5}{|l|}{ Education } \\
\hline Low (ref.) & & I & & । \\
\hline Middle & & 1.78****** & & 0.92 \\
\hline High & & |.9|米米 & & $0.64 *$ \\
\hline Nagelkerke $R^{2}$ & 0.13 & 0.15 & 0.05 & 0.06 \\
\hline Constant & 0.39*** & 0.35 *** & 3.64米米 & 3.7| ***** \\
\hline$n$ & 1680 & 1679 & 1679 & 1677 \\
\hline
\end{tabular}

Levels of significance: ${ }^{*} p<0.05$; ** $p<0.01$; *** $p<0.001$.

benefit from increased union cooperation. As Saco members generally have higher education than LO members, the difference between affiliates of the two unions is clearly reduced and is no longer statistically significant. The score for the non-unionized conversely turns out to be even lower in Model 2. Being entrusted as a union representative is not much affected by the entry of education as a control variable. Likewise, the results regarding sex and age differences basically remain unchanged.

As to the second item in Table 5, Model 1 shows significantly lower coefficients for TCO and Saco members than for LO members. Somewhat surprisingly, the non-unionized also score lower. Being a union representative and having participated in union activities do not come out as very important. Moreover, there are no significant differences between men and women or between age categories. In contrast, employees in the public sector were less prone to agree with the statement than private sector employees.

Model 2 discloses that education is again a crucial factor. People with higher education were less inclined to approve that Swedish unions should pay less attention to EU-level issues 
but rather focus more on improving working conditions in Sweden. With control for education, the differences related to union affiliation become insignificant, except for that between the non-unionized and the reference category; employees who were not organized tended to agree with the statement to a lesser degree. The gap between public and private sector employees is not much affected by the introduction of education as a control variable.

\section{Logic of influence or logic of membership?}

As pointed out before, we also have some data more directly related to the distinction between logic of influence and logic of membership. Table 6 includes the answers from the trade unions on the three above-mentioned statements regarding the role of ETUC.

Concerning the first of these, the respondents generally seem to be skeptical: $86 \%$ of the LO unions, $70 \%$ of the TCO unions, and 79\% of the Saco unions answered "No, not at all" or "Only to a low degree." None of them selected the alternative "Yes, to a high degree." Most of the organizations were thus strongly or rather unwilling to transfer authority to the ETUC. With the small number of responding units, it is difficult to see whether there are any significant differences between the trade unions due to which peak-level organization they were associated with.

Table 6 Degree of agreement among Swedish unions with various statements on the role of the ETUC. (in percentages).

\begin{tabular}{lcccccc}
\hline $\begin{array}{l}\text { "To increase their power and } \\
\text { influence, the ETUC member } \\
\text { organizations must be prepared to } \\
\text { transfer authority to the ETUC" }\end{array}$ & $\begin{array}{c}\text { Yes, to a } \\
\text { high degree }\end{array}$ & $\begin{array}{c}\text { Yes, to } \\
\text { some } \\
\text { degree }\end{array}$ & $\begin{array}{c}\text { Only to a } \\
\text { low degree }\end{array}$ & $\begin{array}{c}\text { No, not } \\
\text { at all }\end{array}$ & $\begin{array}{c}\text { Do not } \\
\text { know }\end{array}$ & Total \\
\hline LO & 0 & 14 & 57 & 29 & 0 & $100(14)$ \\
\hline TCO & 0 & 30 & 20 & 50 & 0 & $100(10)$ \\
\hline Saco & 0 & 14 & 43 & 36 & 7 & $100(14)$ \\
\hline Total & 0 & 18 & 42 & 37 & 3 & $100(38)$ \\
\hline
\end{tabular}

"It is necessary for the ETUC to adapt its aims and methods to the actual decision-making processes in the EU"

\begin{tabular}{lcccccc}
\hline $\mathrm{LO}$ & 29 & 50 & 21 & 0 & 0 & $100(14)$ \\
\hline TCO & 20 & 60 & 0 & 0 & 20 & $100(10)$ \\
\hline Saco & 27 & 67 & 0 & 0 & 7 & $100(15)$ \\
\hline Total & 26 & 59 & 8 & 0 & 8 & $100(39)$ \\
\hline
\end{tabular}

"The ETUC should increase its efforts to mobilize and pursue the interests of its member organisations"

\begin{tabular}{lcccccc}
\hline LO & 36 & 64 & 0 & 0 & 0 & $100(14)$ \\
\hline TCO & 0 & 70 & 10 & 0 & 20 & $100(10)$ \\
\hline Saco & 7 & 53 & 20 & 7 & 13 & $100(15)$ \\
\hline Total & 15 & 62 & 10 & 3 & 10 & $100(39)$ \\
\hline
\end{tabular}


On the second item, respondents were more positive: $79 \%$ of the LO unions, $80 \%$ of the TCO unions, and $94 \%$ of the Saco unions selected "Yes, to a high degree" or "Yes, to some degree." The vast majority of answers were very or rather much in favor of an ETUC policy in which the aims and methods are adapted to the EU's decision-making processes. Three LO unions answered "Only to a low degree" and a few affiliated with the TCO and Saco could not provide an opinion, but we can hardly conclude that there were distinct differences between the unions owing to their peak-level organization.

With respect to the third, the "mobilization" statement, all the LO unions agreed to a high or some degree, but the corresponding proportions among TCO and Saco unions were only $70 \%$ and $60 \%$, respectively. There are in other words some signs among the latter organizations of a skeptical attitude in relation to the statement, whereas the LO unions obviously had no strong objections to the measures referred to.

The main conclusions of the data presented in Table 6 seem to be that most Swedish trade unions were very or rather reluctant to delegate more authority to the ETUC, although they agreed that this confederation must adapt its aims and methods to the actual decision-making processes in the EU. Moreover, they generally wished the ETUC to put more effort in mobilizing and pursuing the interests of its member organizations.

\section{Concluding discussion}

In this article, we have studied the views among Swedish trade unions and Swedish employees-that are to a large extent unionized-regarding cross-national union cooperation in Europe or the EU. Data are taken from two different surveys, one from 2010-2011 and the other from 2006. Whereas most trade unions agreed that, in the long run, cross-national union cooperation will improve the conditions for wage-earners in Europe, employees and union members were more reluctant to endorse this. At first glance, we found some differences between LO members (manual workers) and Saco members (professionals), but after control for education, these differences could not be verified statistically. A higher level of education turned out to be linked to more positive attitudes toward union cooperation in the EU.

A striking result is that employees-unionized and non-unionized-very often answered that they did not know. How can the high proportion of such responses be interpreted? One possible explanation is that the issue of cross-national union cooperation is not really articulated by trade union officials and accordingly perceived as difficult to consider by the members.

On another survey item, respondents were asked whether trade unions should engage less in European or EU-level issues. Almost all the union representatives disagreed, while about half of the respondents in the employee survey said that this statement corresponded very well or rather well with their own opinion. However, as pointed out above, to some extent, the wordings of the two statements differ, which might explain some of the huge disparity between the results for the two categories. Again, the proportion of employees answering that they did not know was substantial, although it was much lower than on the first item. We also discovered differences between LO, TCO, and Saco members- the former were most inclined to say that unions should engage less in EU issues-but once more these differences do not remain statistically significant, when we control for education that had similar effects as on the previous item. 
It can be concluded that trade unions are more open than their members to crossnational union cooperation in Europe and less ready to play down European issues. We can recall that Swedish union members ranked union cooperation in Europe number 15 of 18 among tasks that the union should work with (LO 2012, pp. 42-44). There is obviously a gap in these respects between the organizations and their followers and this gap appears to be larger in the LO than in Saco, with the TCO somewhere in the middle. The question can then be raised how trade unions-and in particular LO unions-relate to their members' views and demands. Are they simply guided by logic-of-influence considerations (cf. Dølvik 1997; Dølvik and Visser 2001; Hyman 2005)? In the union survey, they generally endorsed that the ETUC needs to alter aims and methods in accordance with EU decision-making processes. This might be interpreted as a sign of a logic-of-influence attitude, but at the same time it can be considered self-evident to concur with such a statement. When trade unions were asked about transferring authority to the ETUC, they mostly answered in the negative. More than anything else, these answers indicate an unwillingness to transmit power to others. Notably, most organizations agreed to a high or to some degree that "the ETUC should increase its efforts to mobilize and pursue the interests of their member organizations." Whether this is a wish for higher mobilization from below can however be questioned, because the statement just talks about a top-down initiative. Nevertheless, it must be regarded as a wish for not leaving members behind but instead engaging them in various activities.

Swedish trade unions are undoubtedly more positive than their members to transnational union cooperation and engagement in EU-level issues, but this difference does not allow us to draw any firm conclusions on the issues related to the twin concepts of logic of influence and logic of membership. We might read some of the results in our study as expressions of a logic-of-influence perspective, but there are also other conceivable interpretations. Trade unions probably know more about what is going on in Europe, how it affects domestic labor markets and working conditions, and what would be the consequences of non-participation in European affairs. At the same time, they are well aware that their members are typically more negative to the EU project as a whole and to Swedish unions' engagement in it. Therefore, they try to balance different interests.

As the number of trade unions in our survey is rather small (39), it is difficult to draw conclusions regarding differences between the three peak-level organizationsLO, TCO, and Saco. There are mainly two items on which we have some hint that the three differ. The first item is the statement "Union cooperation will, in the long run, improve the conditions for wage-earners in the EU," where only $40 \%$ of Saco member organizations agreed to a very high degree, while the corresponding proportions for LO and TCO member organizations were twice as high. At the same time, however, $47 \%$ of the former unions answered "Yes, to some degree," compared to about $20 \%$ of LO and TCO unions. Hence, almost all organizations agreed, but there was more reluctance within Saco to agree strongly. A content analysis of trade unions' official stance toward international issues such as transnational cooperation supports the conclusion that Saco unions are less interested (Peterson et al. 2012, p. 632).

The second item on which we have some indication of differences across the peak-level organizations is the mobilization issue. In this case, all 14 LO unions agreed to a high degree or to some degree, whereas $70 \%$ of the 10 TCO organizations and $60 \%$ of the 15 Saco organizations did the same. This might suggest a greater willingness within the LO family to mobilize members, but the data do not allow any far-reaching conclusions. 
Swedish unions are characterized by being strongly class based. It has been claimed that Sweden has "the most socially segregated union movement in the world" (Kjellberg 2011, p. 53). We could, therefore, expect differences in the attitudes to cross-national union cooperation between LO, TCO, and Saco members, which is also confirmed here. As mentioned above, education is an important explanatory factor behind these differences. Highly educated individuals were more positive to cooperation and more negative to union withdrawal from EU engagement. This is in line with research emphasizing that educational level is crucial for ideological orientations (e.g., Bengtsson et al. forthcoming; Stubager 2008). People with lower education tend to support "traditional values, opposition to immigration, and defense of the national community" and for them European integration could be perceived as a threat to national sovereignty (Hooghe et al. 2002, p. 976).

The results in our study may also support the view of the EU as an elite project (cf. Hooghe and Marks 2006; Hyman 2005; Kohli 2000), but we should then keep in mind that quite a few Saco member organizations were hesitant to approve of transnational union cooperation. Nevertheless, it appears that organizational as well as educational elites-if we can use these terms-are relatively more sympathetic to engagement in EU issues.

\section{Funding}

We are grateful to Forskningsrådet för arbetsliv och socialvetenskap (the Swedish Council for Working Life and Social Research) for funding the research project (2008-0246) on which this article is based.

\section{References}

Andersen, S. K. (2006) 'Nordic metal trade unions on the move: responses to globalization and Europeanization', European Journal of Industrial Relations 12(1): 29-47.

Archer, C. (2000) 'Euroscepticism in the Nordic region', Journal of European Integration 22(1): 87-114.

Aylott, N. (2005) 'Lessons Learned, Lessons Forgotten: The Swedish referendum on EMU of September 2003', Government and Opposition 40(4): 540-564.

Bengtsson, M., Berglund, T., and Oskarson, M. (forthcoming) 'Class and ideological orientations revisited: an exploration of class-based mechanisms', British Journal of Sociology (in print).

Blomqvist, P. and Murhem, S. (2003) Fackliga strategier för att möta globalisering och regionalisering inom metallindustrin: En jämförande studie av fyra nordiska länder (Union strategies to meet globalization and regionalization in the metal industry: A comparative study of four Nordic countries). Report no. 3. Stockholm: National Institute for Working Life, Sweden.

Busemeyer, M. R., Kellermann, C., Petring, A. and Stuchlík, A. (2008) 'Overstretching solidarity? Trade unions' national perspectives on the European economic and social model', Transfer 14(3): 435-452.

Dølvik, J.-E. (1997) Redrawing Boundaries of Solidarity? Oslo: FAFO.

Dølvik, J.-E. and Visser, J. (2001) 'ETUC and European Social Partnership: A Third TurningPoint?' In: Compston, H. and Greeenwood, J. (eds) Social Partnership in the European Union. Houndmills, Basingstoke: Palgrave, pp. 11-40. 
Dølvik, J.-E. and Visser, J. (2009) 'Free movement, equal treatment and workers' rights: can the European Union solve its trilemma of fundamental principles?' Industrial Relations Journal 40(6): 491-509.

Eldring, L. and Alsos, K. (2012) European Minimum Wage: A Nordic Outlook. Report no. 16. Oslo: FAFO.

ETUC (2011) Strategy and Action Plan 2011-2015. Brussels: European Trade Union Confederation.

Furåker, B. and Bengtsson, M. (2013) 'On the road to transnational cooperation? Results from a survey of European trade unions', European Journal of Industrial Relations 19(2): 161-177.

Furåker, B. and Lovén Seldén, K. (forthcoming 2013) 'Trade union cooperation on statutory minimum wages? A study of European trade union positions', Transfer (in print).

Glassner, V. and Vandaele, K. (2012) 'Which way towards Europeanisation of trade union strategies? Regional differences in trade union officers' views.' In: 16th World Congress of ILERA, Philadelphia, USA, July 2-5, 2012.

Gstöhl, S. (2002) Reluctant European: Norway, Sweden, and Switzerland in the Process of Integration. Boulder, CO: Lynne Rienner Publishers.

Holmberg, S. (2012) Swedish Opinion on the Swedish Membership in the European Union. SOM Report no. 2012:5, University of Gothenburg, Sweden.

Hooghe, L. and Marks, G. (2006) 'Europe's blues: theoretical soul-searching after the rejection of the European constitution', PS: Political Science \& Politics 39(2): 247-250.

Hooghe, L., Marks, G. and Wilson, C. J. (2002) 'Does left/right structure party positions on European integration?' Comparative Political Studies 35(8): 965-989.

Hyman, R. (2005) 'Trade unions and the politics of the European social model', Economic and Industrial Democracy 26(1): 9-40.

Hyman, R. (2009) Trade Unions and 'Europe': Are the Members out of Step? LEQS Paper no. 4. London School of Economics, UK.

Kjellberg, A. (2011) 'Trade Unions and Collective Agreements in a Changing World.' In: Thörnquist, A. and Engstrand, Å.-K. (eds) Precarious Employment in Perspective. Old and New Challenges to Working Conditions in Sweden. Brussels: P.I.E. Peter Lang, pp. 47-100.

Kohli, M. (2000) 'The battlegrounds of European identity', European Societies 2(2): 113-137.

LO (2012) Röster om facket och jobbet: Fackets uppgifter, fackets inflytande och fackligpolitisk samverkan. Report no. 4. LO, Sweden.

Magnusson, L. and Murhem, S. (2009) 'European integration and Nordic trade unions.' In: Götz, N. and Haggrén, H. (eds) Regional Cooperation and International Organizations: The Nordic Model in Transnational Alignment. London: Routledge, pp. 185-200.

Martin, A. and Ross, G. (2001) 'Trade Union Organizing at the European Level: The Dilemma of Borrowed Resources.' In: Imig, D. and Tarrow, S. (eds) Contentious Europeans: Protest and Politics in an Emerging Polity. Lanham: Rowman \& Littlefield, pp. 53-76.

Miljan, T. (1977) The Reluctant Europeans: The Attitudes of the Nordic Countries towards European Integration. London: C. Hurst \& Company.

Peterson, A., Wahlström, M. and Wennerhag, M. (2012) 'Swedish trade unionism: A renewed social movement?' Economic and Industrial Democracy 33(4): 621-647.

Schmitter, P. C. and Streeck, W. (1999) The Organization of Business Interests: Studying the Associative Action of Business in Advanced Industrial Societies. MPIfG Discussion paper 99/1. Max-Planck-Institut für Gesellschaftsforschung, Germany.

Schulten, T. (2008) 'Towards a European minimum wage policy? Fair wages and social Europe', European Journal of Industrial Relations 14(4): 421-439. 
Schulten, T. and Watt, A. (2007) European Minimum Wage Policy-A Concrete Project for a Social Europe. European Economic and Employment Policy Brief no. 2. ETUI-REHS, Belgium.

Stubager, R. (2008) 'Education effects on authoritarian-libertarian values: a question of socialization', British Journal of Sociology 59(2): 327-350.

Vaughan-Whitehead, D. (ed.) (2010) The Minimum Wage Revisited in the Enlarged EU. Cheltenham, UK: Edward Elgar.

Widfeldt, A. (2004) 'Elite collusion and public defiance: Sweden's Euro referendum in 2003', West European Politics 27(3): 503-515. 